\title{
Genetic Heterogeneity, Therapeutic Hurdle Confronting Sorafenib and Immune Checkpoint Inhibitors in Hepatocellular Carcinoma
}

\author{
Sara M. Atwa ${ }^{1,2}$, Margarete Odenthal ${ }^{3}$ (D) and Hend M. El Tayebi ${ }^{2, *(D)}$ \\ 1 Pharmaceutical Biology Department, German University in Cairo, Cairo 11865, Egypt; \\ sara.mahmoud-atwa@guc.edu.eg \\ 2 Molecular Pharmacology Research Group, Department of Pharmacology and Toxicology, Faculty of \\ Pharmacy and Biotechnology, German University in Cairo, Cairo 11835, Egypt \\ 3 Institute for Pathology, University Hospital Cologne, 50924 Cologne, Germany; m.odenthal@uni-koeln.de \\ * Correspondence: hend.saber@guc.edu.eg
}

check for

updates

Citation: Atwa, S.M.; Odenthal, M.; El Tayebi, H.M. Genetic

Heterogeneity, Therapeutic Hurdle

Confronting Sorafenib and Immune

Checkpoint Inhibitors in

Hepatocellular Carcinoma. Cancers

2021, 13, 4343. https://doi.org/

$10.3390 /$ cancers 13174343

Academic Editors: Rocio I. R. Macias, Oscar Briz and Jose J. G. Marin

Received: 14 July 2021

Accepted: 5 August 2021

Published: 27 August 2021

Publisher's Note: MDPI stays neutral with regard to jurisdictional claims in published maps and institutional affiliations.

Copyright: (c) 2021 by the authors. Licensee MDPI, Basel, Switzerland. This article is an open access article distributed under the terms and conditions of the Creative Commons Attribution (CC BY) license (https:/ / creativecommons.org/licenses/by/ $4.0 /)$.
Simple Summary: Hepatocellular carcinoma (HCC) represents a worldwide health challenge, ranking globally as the third most common cause of cancer-related mortality. Current advancements in the HCC therapeutic armamentarium succeeded in challenging HCC conventional therapy. Systemic therapies including tyrosine kinase inhibitors and immune checkpoint inhibitors (ICIs) come at the forefront of novel HCC therapeutic modalities. However, emerging drug resistance remains an obstacle during HCC therapy. According to the ongoing genomic analysis of HCC, a complex mutational landscape lies behind HCC pathogenesis and hence, affects the response of the tumor to the applied therapy. This review aims at categorizing and summarizing the different resistance mechanisms confronting tyrosine kinase inhibitors, represented by sorafenib, as well as ICIs, during HCC therapy. In addition, giving an insight into how genomic heterogeneity can influence the response of HCC to the aforementioned therapies.

Abstract: Despite the latest advances in hepatocellular carcinoma (HCC) screening and treatment modalities, HCC is still representing a global burden. Most HCC patients present at later stages to an extent that conventional curative options are ineffective. Hence, systemic therapy represented by the tyrosine kinase inhibitor, sorafenib, in the first-line setting is the main treatment modality for advanced-stage HCC. However, in the two groundbreaking phase III clinical trials, the SHARP and Asia-Pacific trials, sorafenib has demonstrated a modest prolongation of overall survival in almost $30 \%$ of HCC patients. As HCC develops in an immune-rich milieu, particular attention has been placed on immune checkpoint inhibitors (ICIs) as a novel therapeutic modality for HCC. Yet, HCC therapy is hampered by the resistance to chemotherapeutic drugs and the subsequent tumor recurrence. HCC is characterized by substantial genomic heterogeneity that has an impact on cellular response to the applied therapy. And hence, this review aims at giving an insight into the therapeutic impact and the different mechanisms of resistance to sorafenib and ICIs as well as, discussing the genomic heterogeneity associated with such mechanisms.

Keywords: ANGPT-2; cell death; drug resistance; drug transport; eNOS; genetic variants; immune checkpoint; liver cancer; signaling pathways; sorafenib

\section{Introduction}

Liver cancer ranks globally as the third leading cause of cancer-related mortality [1] with hepatocellular carcinoma (HCC) accounting for 70-90\% of total primary liver cancers [2]. HCC is a multi-factorial, multistep and complex process. It is characterized by its rapid infiltrating growth, metastasis in early-stage, high-grade malignancy, and poor therapeutic efficacy [3]. The majority of HCC patients present at an advanced stage (Barcelona 
Clinic Liver Cancer stage B or higher), albeit implemented surveillance programs, rendering the curative modalities as radical resection, transplantation, and percutaneous ablation procedures ineffective [3]. Accordingly, systemic treatment of advanced HCC has received the spotlight. Molecular targeted therapy has witnessed a major breakthrough with the approval of sorafenib [4,5]. However, both the SHARP and Asia-Pacific trials engaged in sorafenib approval and revealed a significant improvement in survival benefit of advanced HCC patients, yet the increment in overall survival (OS) manifested in approximately $30 \%$ of enrolled patients, was only 2 to 3 months [4,5]. A decade thereafter, phase II and III clinical trials were inaugurated, to test several molecularly targeted mediators, though most of such trials showed non-superiority in survival benefits for advanced HCC patients or treatments were accompanied with severe adverse effects [6]. Nevertheless, a number of molecularly targeted mediators exhibited improved clinical efficacy in phase III clinical trials including lenvatinib that was approved as a first-line therapy [7]. In addition, regorafenib, cabozantinib, and ramucirumab were recommended for the second-line setting [8].

Meanwhile, substantial progress in finding alternatives for HCC patients, who were not successfully treated by the first-line setting, was enforced. Recently, treatment with immune checkpoint inhibitors (ICIs) has emerged as a promising therapeutic option for patients with advanced HCC. Physiologically, immune checkpoints are co-inhibitory molecules that act as "brakes" over the immune system to avoid an exaggerated response and restore its activity to a normal level, thus maintaining an immune balance [9]. HCC mostly arises on a background of chronic inflammation-inducing $\mathrm{T}$ cell exhaustion, a state that is characterized by an increased expression of co-inhibitory receptors including programmed cell death-1 (PD-1) and cytotoxic T-lymphocyte associated protein-4 (CTLA-4) [10]. Engagement of co-inhibitory receptors with their ligands is one arm of escaping immune surveillance through attenuating the cytotoxic activity of $\mathrm{T}$ cells and thus tumor progression [11]. Indeed, this was one rationale for developing immunotherapeutic techniques for HCC [12], as inhibition of immune checkpoints can aid at leveraging the anti-tumor immune response mediated through cytotoxic T cells. Currently, two classes of ICIs, targeting PD-1 or CTLA-4, are clinically approved or still under investigation for safety and efficacy profiles [13].

Despite the gained momentum in advanced HCC therapeutic modalities, the emergence of drug resistance remains an obstacle. An extensive genomic analysis of primary and recurrent HCC has revealed a complex mutational landscape that could be integrated into drug resistance, thus further understanding of the genomic background of HCC is essential to overcome therapeutic challenges [14]. In the present review, we are focusing on the therapeutic impact of sorafenib and ICI treatment strategies, their benefits as well as discussing their mechanisms of resistance together with the related genomic background. To achieve the purpose of the review, research was conducted at the States National Library of Medicine (PubMed). For the search in databases, the descriptors used were: "drug resistance", "sorafenib", "immunotherapy resistance" in combination with "HCC", "Liver cancer" and "genetic variants", "mutations". Research papers and published data were reviewed for their relevance to the aim of the review and summarized. Criteria for inclusion were complete, relevant publication, available online, in English, published mostly between 2008 and 2020.

\section{HCC Conventional Therapy}

HCC management is a challenging process owing to the possible complex underlying co-morbidities and tumor extent as well as the severity of liver dysfunction [15]. Accordingly, HCC treatment-decision making is a multiple-disciplinary approach that requires a high level of expertise to achieve an optimum patient outcome [16]. Despite the curative potential of radical treatments such as surgical resection and transplantation, they are recommended solely for early-stage HCC [17], yet more than two-thirds of HCC patients present at an advanced stage [18]. Besides, one major drawback for surgical resection is 
that almost 70\% of patients develop recurrent HCC post-resection [19]. On the other hand, liver transplantation is considered the definitive treatment modality as it not only removes the existing detectable tumor but also removes the unhealthy liver as well as the preneoplastic lesions within the cirrhotic tissues [18]. Percutaneous local ablation procedures as radiofrequency ablation and percutaneous alcohol injection are recommended for small tumors in patients who are ineligible for tumor resection [20]. Moreover, patients with unresectable tumors and no vascular invasion or metastasis, are eligible for transarterial chemoembolization (TACE) [21]. TACE is mostly coupled with targeted delivery of cytotoxic chemotherapeutic agents as doxorubicin, epirubicin, or cisplatin, thus decrease tumor progression and improve OS [22]. TACE is frequently used as a bridging modality to downsize the tumor prior to liver transplantation [23]. Nevertheless, the aforementioned treatment modalities are not effective for advanced HCC, thus targeted treatments have emerged as a promising technique.

\section{Sorafenib as a Frontline Therapy for Advanced HCC}

After the molecular revolution in the 1980s and a better understanding of cancer etiologies, the development of novel therapies targeting specific pathways in cancers has evolved since then. In 1994, a collaboration project was inaugurated between Bayer and Onyx, in which they focused on the discovery of the Ras/Raf/MEK/ERK pathway as a novel therapeutic target. High throughput screening for Raf 1 kinase inhibitory activities has identified a lead compound that was optimized than to give sorafenib [24]. In 2007, the European Medicines Agency and Food and Drug Administration (FDA) approved sorafenib as a first-line treatment for advanced HCC [5]. Since then, several phase 3 clinical trials have studied other drugs compared with sorafenib in the same setting of advanced HCC, yet none of them showed superior outcomes over sorafenib [25-28].

Sorafenib is an oral multikinase inhibitor that exerts its anti-tumor activity by inhibiting both, tumor cell survival as well as tumor vascularization [29]. Notably, it has been reported that deregulation in Raf/MEK/ERK pathway has a critical role in HCC development [30]. The anti-proliferative activity of sorafenib was manifested by its interruption of the Raf/MEK/ERK pathway by inhibition of Raf serine-threonine kinases [31]. In addition, sorafenib has been demonstrated to mediate anti-angiogenic activity through targeting receptor tyrosine kinases including vascular endothelial growth factor receptor (VEGFR2 \& VEGFR3), platelet-derived growth factor receptor (PDGFR) as well as mast/stem cell growth factor receptor (c-Kit) [32].

Two groundbreaking phase III randomized, multicenter, double-blind, placebo-controlled studies were pivotal in the approval of sorafenib therapy for advanced HCC. The Sorafenib Hepatocarcinoma Assessment Randomized Protocol (SHARP) study revealed that sorafenib can prolong the median overall survival (OS) for approximately three months (10.7 vs. 7.9, sorafenib vs. placebo) [5]. In addition to the Asia-Pacific trial that demonstrated a marginal improvement in median OS (6.5 months vs. 4.2 months, sorafenib vs. placebo) [4]. Since then, sorafenib has prevailed as the therapeutic armamentarium against advanced HCC [8]. Nevertheless, it is noteworthy that both studies declared that the OS rate was manifested in approximately $30 \%$ of patients [4,5], a modest response that could be attributed to inherent or acquired resistance to sorafenib [33].

\subsection{Mechanisms of Sorafenib Resistance and the Related Genomic Background}

Intratumor heterogeneity is a pivotal reason that leads to the emergence of drug resistance in tumors (Table 1). Cancer drug resistance is classified into two types. The intrinsic drug resistance occurs prior to the drug exposure and allows the resistant cancer cells to proliferate and form a tumor mass insensitive to chemotherapy. While acquired drug resistance occurs after drug exposure, in which cancer cells develop resistant techniques to halt chemotherapy-mediated cytotoxicity [34]. As illustrated in Figure 1, the emerged drug resistance involves a complex of mechanisms that are related to the transport of drugs across the cell membrane, imbalance in the regulation of cell death through apoptosis 
and autophagy, genetic variations in the molecular targets and pathways as well as other miscellaneous mutations that enhance drug resistance as those occurring in Angiopoietin-2 gene (ANGPT-2) and Nitric oxide synthase-3 gene (NOS-3).

Table 1. Genetic polymorphisms in HCC and their impact on sorafenib efficacy.

\begin{tabular}{|c|c|c|c|c|c|c|}
\hline Gene & & & Genotype & Reference SNP & Consequences & Reference \\
\hline$A B C B 1$ & \multirow{4}{*}{ Export Pumps } & MDR1 & $3435 \mathrm{C}>\mathrm{T}$ & rs2032582 & Reduced sorafenib plasma levels & [35] \\
\hline$A B C C 2$ & & MRP2 & $1249 \mathrm{G}>\mathrm{A}$ & rs2273697 & Reduced sensitivity & [36] \\
\hline \multirow{2}{*}{$B C R P$} & & \multirow{2}{*}{ ABCG2 } & $34 \mathrm{G}>\mathrm{A}$ & rs2,231,137 & Reduced sorafenib plasma levels & \multirow{2}{*}{ [35] } \\
\hline & & & $1143 \mathrm{C}>\mathrm{T}$ & rs $2,622,604 \mathrm{~T}$ & Reduced sorafenib plasma levels & \\
\hline \multirow{6}{*}{ SLC22A1 } & \multirow{7}{*}{ Uptake carriers } & \multirow{6}{*}{ OCT1 } & R61S fs *10 & novel & Reduced sensitivity & \multirow{2}{*}{ [37] } \\
\hline & & & C $88 \mathrm{~A} \mathrm{fs} * 16$ & novel & Reduced sensitivity & \\
\hline & & & c. $262 \mathrm{~T}>\mathrm{C}$ & rs1001179 & Reduced sensitivity & \multirow{4}{*}{ [38] } \\
\hline & & & c. $566 \mathrm{C}>\mathrm{T}$ & rs34104736 & Reduced sensitivity & \\
\hline & & & c. $659 \mathrm{G}>\mathrm{T}$ & rs36103319 & Reduced sensitivity & \\
\hline & & & c. $859 \mathrm{C}>\mathrm{G}$ & rs4646278 & Reduced sensitivity & \\
\hline SLC15A2 & & PEPT2 & $1048 \mathrm{~T} / \mathrm{T} \& \mathrm{C} / \mathrm{T}$ & rs2257212 & Prolonged PFS & {$[39,40]$} \\
\hline \multirow[t]{2}{*}{$K D R$} & \multirow{4}{*}{ Drug target } & \multirow{2}{*}{ VEGFR2 } & AA genotype & rs1870377 & $\begin{array}{l}\text { Improved response to sorafenib } \\
\text { and longer TTP }\end{array}$ & \multirow{2}{*}{ [41] } \\
\hline & & & CC genotype & rs2071559 & Shorter OS & \\
\hline \multirow{2}{*}{$V E G F$} & & VEGF-A & C allele & rs2010963 & Reduced OS and PFS & \multirow{2}{*}{ [42] } \\
\hline & & VEGF-C & $\mathrm{T}$ allele & rs4604006 & Reduced OS and PFS & \\
\hline \multirow{2}{*}{ NOS3 } & \multirow{2}{*}{\multicolumn{2}{|c|}{ eNOS }} & eNOS-786 TT & rs2070744 & Reduced OS and PFS & [43] \\
\hline & & & $e N O S+894 \mathrm{GG}$ & rs1799983 & Reduced OS and PFS & [44] \\
\hline \multirow[b]{3}{*}{ ANGPT2 } & \multirow{3}{*}{\multicolumn{2}{|c|}{ ANGPT2 }} & TT/GT & rs55633437 & Reduced OS and PFS & \multirow[b]{3}{*}{ [44] } \\
\hline & & & \multicolumn{2}{|c|}{ Haplotype (HT2) } & \multirow[b]{2}{*}{ Reduced OS and PFS } & \\
\hline & & & $\begin{array}{l}\mathrm{T} \\
\mathrm{T} \\
\mathrm{G}\end{array}$ & $\begin{array}{l}\text { rs3739392 } \\
\text { rs3739391 } \\
\text { rs3739390 }\end{array}$ & & \\
\hline
\end{tabular}

OS: overall survival, PFS: Progression-free survival, TTP: time to progression. SNP: Single nucleotide polymorphism. *: position of new termination site represented by position number folowing.

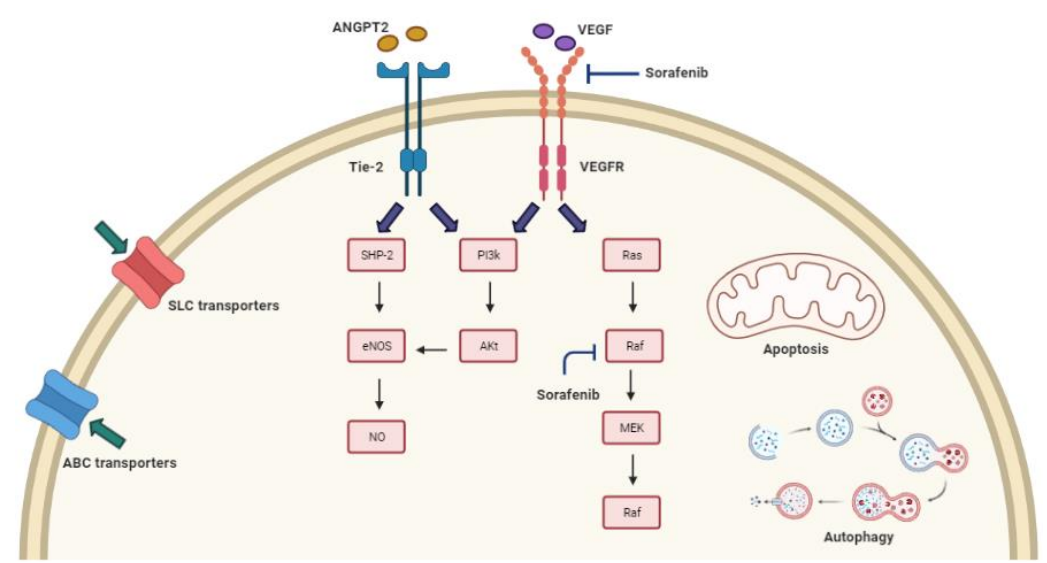

Figure 1. Resistance mechanisms to sorafenib in HCC patients; sorafenib resistance developing in HCC patients can be attributed to a complex of mechanisms, including Transport of the drug across the cell membrane, deregulated cell death mechanisms, the genetic variability of molecular targets and pathways as well as miscellaneous mutations including ANGPT-2 and NOS-3 genes. ABC: ATP-binding cassette; SLC: solute carrier; ANGPT-2: angiopoietin-2; Tie-2: type-I tyrosine kinase receptors; VEGF: vascular endothelial growth factor; VEGFR: vascular endothelial growth factor receptor; eNOS: endothelial nitric oxide synthase; NO: nitric oxide. 


\subsection{Sorafenib Resistance and Drug Transport across Cell Membrane}

One pillar of drug resistance mechanisms is mediated by integral membrane transporters, implicated in increased drug efflux or reduced drug uptake [45]. Physiologically, human hepatocytes express multiple transporters that are capable of uptaking endogenous substances and drugs across the sinusoidal membrane as well as their efflux into bile [46]. In HCC therapeutic framework, two large families of membrane transporters are involved in drug resistance, the efflux ATP-binding cassette $(\mathrm{ABC})$ transporters and the solute carrier (SLC) superfamily uptake transporters.

\subsubsection{ABC Transporters}

The $A B C$ transporters are a superfamily of integral membrane proteins that are ubiquitously found in prokaryotes and eukaryotes [47]. A functional ABC transporter typically contains two transmembrane domains (TMD) and two nucleotide-binding domains (NBD) or ATP-binding cassettes [48]. ABC transporters have a mainstay role in determining the bioavailability of a plethora of drugs including anti-neoplastic drugs and thus have a major contribution to drug resistance modulation [49]. In human, $A B C$ transporters family include 51 genes, three of which are pseudogenes, classified into seven families (A-G) based on their gene structure and sequence homology in both TMD and NBD [48,50].

A recent high throughput study by next-generation sequencing has demonstrated the ethno-geographic related genetic variability of $A B C$ transporter family over 138,000 individuals across seven populations. This could be a proposed plausible explanation for the inter-individual differences in drug responses [51]. Of note, clinically related variants of $\mathrm{ABC}$ transporter family members, $\mathrm{ABCB}, \mathrm{ABCC}$, and $\mathrm{ABCG} 2$ were found to be implicated in chemotherapy resistance [52]. Single nucleotide polymorphisms (SNPs) are one type of genetic variability that is extensively studied in $A B C$ transporters. A recent study showed that $A B C B 1$, encoding for multidrug resistance protein 1 (MDR1), genetic variant rs2032582 ( $3435 \mathrm{C}>\mathrm{T}$ ) is associated with the lowest sorafenib plasma levels in HCC patients and hence, is related to sorafenib resistance [35]. Furthermore, an interesting finding was elaborated by a study conducted on the Chinese population, in which SNPs in $A B C B 1$ $(335 \mathrm{~T}>\mathrm{C}, 3073 \mathrm{~A}>\mathrm{C}, 3751 \mathrm{G}>\mathrm{A}$, and $4125 \mathrm{~A}>\mathrm{C})$ were associated with the risk of HCC development [53-55].

Multidrug resistance-associated protein 2 (MRP2) is the functional transporter protein, encoded by the $A B C C 2$ gene. The $A B C C 2$ SNP rs2273697 (1249G > A) has been reported to be associated with increased ATPase activity of MPR2, which in turn induces the efflux of sorafenib and thereby sorafenib resistance [36]. In addition, the ABCC2 transporter has been reported to be overexpressed in HCC compared with adjacent healthy livers [56].

According to Huang et al., the breast cancer resistance protein (BCRP), encoded by $A B C G 2$, has a significant role in shaping the sensitivity of HCC to sorafenib. Experimental data showed that BCRP mediates the efflux of sorafenib, an action that was hampered through combining sorafenib with a BCRP inhibitor [57]. Tandia et al. have proposed that this developed sorafenib resistance can be attributed to SNP occurring in the ABCG2 gene. In agreement, both genetic variants of $A B C G 2$ rs2, 231,137 (34 G > A) and rs2, 622, $604 \mathrm{~T}(1143 \mathrm{C}>\mathrm{T})$ were associated with the low sorafenib plasma levels and improved clinical outcome [35]. It is worth mentioning that genetic polymorphisms of both $A B C B 1$ and $A B C G 2$ in relevance to HCC susceptibility, HCC risk of recurrence following liver transplantation [53] as well as a therapeutic response [58] have been thoroughly studied which provide a solid ground for how genetic variability can implicate HCC since its incidence till therapeutic response.

\subsubsection{SLC Transporters}

The solute carrier $(S L C)$ gene superfamily is the second largest family of membrane transporters consisting of more than 400 membrane-bound proteins classified into $65 \mathrm{sub}$ families based on sequence similarity [59-61]. SLC transporters' activation relies on the generation of an electrochemical potential difference or an ion gradient to enable the 
transportation of their substrates across biological membranes [62]. SLC transporters are involved in a plethora of physiological processes including cellular uptake of nutrients, in addition, their role can be broadened to include the uptake of other xenobiotics, including antineoplastic drugs [63]. A seminal study carried out by Schaller et al. using a bioinformatics analysis on next-generation sequencing (NGS) data from approximately 140,000 individuals from seven major human populations has interestingly reported around 204,000 single-nucleotide variants. Of note, most of the SLC variants that were reported were associated with altered drug responses and toxicity phenotypes [64].

Several studies provided consolidated findings of involvement of SLC22A1 and its protein, organic cation/anion transporter1 (OCT1), in tyrosine-kinase inhibitors' uptake including sorafenib $[37,65]$. Herraez et al. have reported the downregulation of OCT1 in HCC followed by reduced sorafenib uptake and poorer drug response. This study has demonstrated that novel variants including R61S fs*10 and C88A fs*16 induce frameshift thus the production of truncated protein and hence, abolished sorafenib sensitivity [37]. Furthermore, Alonso-Pena et al. have identified several SLC22A1 inactivating variants at a high frequency in HCC such as rs1001179 (c.262T > C), rs34104736 (c.566C > T), rs36103319 (c.659G > T) and rs4646278 (c.859C > G). Moreover, this study has reported other OCT1 mutations including c.262delT (p.Cys88Alafs*16) (*: position of new termination site represented by position number following) and c.181delCGinsT (p.Arg61Serfs*10). Such SNPs and mutations were manifested in lower sorafenib uptake thus, poorer clinical outcomes [38].

Based on a recent study, SLC46A3 varying expression has an impact on sorafenib resistance [66]. According to their findings, SLC46A3 was downregulated in $80 \%$ of studied HCC tissue samples compared to non-tumor adjacent tissues. Furthermore, it was reported that tumors expressing lower levels of SLC46A3 had more aggressive phenotypes and a short survival time post-surgery. In addition, ectopic expression of SLC46A3 was accompanied by enhanced sorafenib uptake and hence, ameliorating sorafenib resistance [66].

A recent genome-wide association study performed by Lee et al. in HCC patients receiving sorafenib has reported a relationship between genetic variants in SLC15A2, encoding for peptide transporter 2 (PEPT2), and sorafenib responsiveness. Lee et al. proposed that patients with genetic variant rs2257212 in SLC15A1 with $1048 \mathrm{~T} / \mathrm{T}$ or C/T genotypes displayed a significantly longer progression-free survival than did patients with C/C genotypes [39].

\subsection{Sorafenib Resistance and Imbalance in the Regulation of Cell Death}

Regulated cell death is described as the death response of cells to changes in their microenvironment when other adaptive responses cannot regain cell homeostasis. It can be classified, based on the molecular mechanisms into autophagy, apoptosis, ferroptosis, proptosis, and others $[67,68]$. However, alterations in the pattern of autophagy and apoptosis have been reported to be involved in sorafenib resistance in HCC.

\subsubsection{Autophagy}

Autophagy is an evolutionarily conserved process across eukaryotes, which involves an intracellular catabolic degradation process targeting damaged and superfluous cellular components [69]. Physiologically, autophagy plays a critical role in maintaining cellular homeostasis; however, it could have a paradoxical role in cancer based on the tumor cell context [70]. A basic level of autophagy is sufficient for maintaining genomic stability, thus acting as a cancer suppressor, however, once cancer starts; autophagy is highly activated promoting cancer survival under stress conditions [71]. Moreover, autophagy is thought to contribute to the tumor adaptive response under therapeutic stress, which orchestrates the resistance to treatment [72]. Interestingly, some studies reported that sorafenib induces an autophagic-protective response in HCC cells [73-75]. Shimizu et al. demonstrated that sorafenib treatment was accompanied by the accumulation of autophagosomes, as evidenced by the conversion of LC3-I to LC3-II protein in in-vitro and xenograft HCC 
models [74]. Nonetheless, the exact mechanism, underlying autophagy impact on sorafenib sensitivity needs to be further elucidated [76].

Recent cumulative evidence has indicated that genetic variants of autophagy-related genes (ATGs), that are required for autophagosome formation, strongly correlate with HCC development and progression. Furthermore, a recent study, conducted on Chinese patients suffering from HCC, identified five genetic ATG variants (ATG5 rs17067724, ATG10 rs1864183, ATG10 rs10514231, ATG12 rs26537, and ATG16L1 rs4663402), that were associated with HCC development. In particular, ATG10 rs10514231 showed a highly significant association with the risk of HCC development [77]. Noteworthy, in advanced lung adenocarcinoma, two genetic variants in the ATG10 gene, rs10036653, and rs1864182, were reported to be associated with primary or acquired resistance to a tyrosine kinase inhibitor, gefitinib [78]. Moreover, ATG5 genetic variants rs510432 and rs548234 are linked to the HCC progression based on chronic HBV infection [79,80].

\subsubsection{Apoptosis}

Physiologically, the primary cellular response to non-lethal stress is autophagy [81]. However, an exacerbated stress condition that exceeds a critical duration or an intensity threshold can activate an apoptotic program [82]. Apoptosis is a highly regulated form of programmed cell death, playing a major role in maintaining liver volume and cell number during liver development and regeneration [83]. However, impairment of the fine balance between anti-apoptotic and pro-apoptotic proteins has been linked to hepatocarcinogenesis as well as sorafenib resistance [84]. Shimizu et al. reported that the tumor suppressor miRNA let-7 negatively regulates the expression of the anti-apoptotic Bcl-xl protein in HCC. Hence, the ectopic expression of let-7 miRNA leads to repression of Bcl-xl, which in turn results in sorafenib-mediated toxicity [85]. Additionally, it has been reported that co-administration of the BCL-xl molecular inhibitor, ABT-737, with sorafenib showed enhanced anti-tumoral activity in HCC compared to administration of sorafenib alone [86].

p53 is a tumor suppressor protein, that is involved in cell cycle control, apoptosis, DNA repair, and senescence in response to cellular stress [87]. Tp53 mutations are amongst the most prevalent mutations in HCC that vary based on the tumor etiology [88]. In this sense, aflatoxin B1-induced hepatocarcinogenesis is associated with R249S mutation in the TP53 gene [89]. It has been postulated that HCC cells that are devoid of functional p53 protein are resistant to sorafenib-targeted therapy [90,91]. A recent study investigated the link between p53 status and the effectiveness of four tyrosine kinase inhibitors; sorafenib, regorafenib, lenvatinib, and cabozantinib in HCC cells. This study included a variety of liver cancer cells such as HepG2 cells with wild-type TP53, Hep3B with nonsense-TP53 mutation, SNU423 with inframe TP53 gene deletion, Huh7, and SNU449 with TP53 point mutation. It was postulated then that regorafenib and sorafenib showed high effectiveness in HCC cell lines carrying the wild-type TP53 gene compared to a decreased anti-proliferative and proapoptotic properties in HCC cell lines that lack or have a mutated TP53 variant [88].

\subsection{Sorafenib Resistance Based on Genetic Alterations of Molecular Targets and Signaling Pathways}

Being anti-angiogenic and anti-proliferative, sorafenib has a myriad of molecular targets, that genetic polymorphisms and mutations in their expressing genes would affect the response of HCC to sorafenib treatment. The elevated tissue expression and serum levels of VEGFR, a major regulator of tumor vascularization, have been reported to be associated with poor prognosis of HCC patients [92,93]. Moreover, several studies have demonstrated an association between the clinical outcome in HCC patients receiving sorafenib and SNPs in genes encoding for VEGF signaling pathway molecular components [94]. VEGFR2, also known as kinase insert domain receptor (KDR), is a principal member of the VEGFR family that enhances the pro-angiogenic activity of vascular endothelial growth factor subtype A (VEGF-A) [41]. The aberrant function of KDR has been reported to be associated with vascular endothelial cell damage, impaired endothelial cell survival, and abnormal vascular repair [41]. Wang et al. reported a genetic missense variant c.1416A > T (p.Gln472His, 
rs1870377) in the KDR gene which induces impairment in the binding efficiency of KDR to the VEGF-A ligand [95]. In addition, a study on a Chinese HCC cohort demonstrated the association of wild-type allele (AA) of rs1870377 with diminished progression an improved response to sorafenib in comparison to the heterozygous (TA) or homozygous (TT) genotypes [41]. Moreover, Wang et al. reported a reduced binding efficiency of the transcription factor E2F to the KDR gene promoter associated with the promoter genetic variant of the $K D R$ gene, rs2071559 C > T, due to a subsequent alteration in the E2F binding site [95]. Interestingly, Zheng et al. has deduced that the homozygous genotype for the $C$ allele is associated with a shorter OS in HCC patients treated with sorafenib [41].

In this framework, the ALICE-1 study has been conducted to investigate the impact of genetic polymorphisms in genes encoding for VEGF and the clinical response of HCC patients receiving sorafenib. Based on the findings of this study, it is reported that the combination of VEGF-A allele C of rs2010963 and VEGF-C allele T of rs4604006 has been associated with worsened prognosis of HCC patients receiving sorafenib [42].

Recently, a comprehensive analysis of biomarkers, BIOSTORM, was conducted retrospectively in the setting of a randomized phase 3 STORM study on 83 HCC patients receiving sorafenib compared to 105 receiving placebo. This study has been able to generate a 146-gene panel, composed of 87 "poor prognosis" genes and 59 "good prognosis" genes, which can identify HCC patients who are predicted to benefit from sorafenib. $30 \%$ of the enrolled patients have been identified to benefit from sorafenib in terms of recurrence prevention [96]. Moreover, Harding et al. [97] conducted a study using a hybridization capture-based NGS assay designed to target 341 cancer-associated genes in 127 HCC patients, of which 81 received sorafenib. It was reported that mutations predicted to activate the PI3K-mTOR pathway were associated with poor clinical outcomes in sorafenib-treated patients compared to patients without such mutations. However, based on Harding et al. findings, mutations predicted to activate the WNT or MAPK pathway, TP53 pathway, cell-cycle control, and chromatin remodeling showed no impact on clinical outcomes. Furthermore, this study has demonstrated the null effect of VEGFA amplification on clinical outcome improvement, despite being previously addressed as one of the biomarkers for extreme sorafenib responders [97].

B-RAF, a member of the RAS/RAF/MEK/ERK pathway, is reported to play a critical role in the development of hepatocarcinogenesis. In addition, B-RAF is one of the major kinases targeted by sorafenib; however, mutations in B-RAF have been identified as a driver of sorafenib resistance in the HCC context [98]. A case report for a patient with non-small cell lung cancer (NSCLC), harboring BRAF G469R mutation, showed a strong and rapid response to sorafenib [99]. However, another case report for an NSCLC and HCC patient receiving sorafenib has demonstrated the efficacy of sorafenib in managing the lung lesions with BRAF G469V mutation, while no response was observed in the hepatic lesions with wild-type (wt) B-RAF. Hence, this study suggested that an improved response to sorafenib can be manifested in mutated B-RAF tumor cells which are characterized by constitutive activation of the RAF pathway [100].

\subsection{Sorafenib Resistance and Polymorphisms of eNOS and ANGPT-2 Genes}

It is conceivable that HCC is a hypervascular tumor, in which angiogenesis is a complex and multifactorial process, whose main player is VEGF and its downstream signaling pathway [101]. However, other pathways are incorporated in angiogenesis including the angiopoietin (ANGPT)-Tie system. The human ANGPT-Tie system is composed of two membrane-bound type-I tyrosine kinase receptors (Tie-1 and Tie-2) and three secreted ligands (ANGPT1, ANGPT2, and ANGPT4) [102]. Engagement of ANGPT-2 with its receptor TIE-2 induces the receptor phosphorylation and hence, the activation of downstream effectors including SH2 domain-containing phosphatase (SHP2) and p85 subunit of PI3K. SHP2 and PI3K induce the activity of endothelial nitric oxide synthase (eNOS) which mediate nitric oxide (NO) production [102]. Physiologically, NO mediates several 
angiogenic-related processes and has been reported to play a pro-angiogenic role in tumor vascularization [103].

Recent reports documented that gene polymorphisms of both eNOS and ANGPT2 genes could be correlated with the clinical outcomes in HCC patients receiving sorafenib $[43,44]$. In the Italian multicenter, retrospective ePHAS (eNOS polymorphisms in HCC and sorafenib) study, the prognostic value of three eNOS polymorphisms, eNOS-786 $\mathrm{T}>\mathrm{C}$ in the promoter region, a $27 \mathrm{bp}$ variable number of tandem repeats in intron 4 (eNOS VNTR $4 \mathrm{a} / \mathrm{b}$ ) and $e N O S+894 \mathrm{G}>\mathrm{T}$ in exon 7 were analyzed in terms of progression-free survival (PFS) and OS. This retrospective study included two independent cohorts of patients, a training cohort of 41 HCC patients and a validation cohort of 87 HCC patients, all receiving sorafenib. In univariate analysis, training cohort patients homozygous for eNOS haplotype (HT1:T-4b at eNOS-786/eNOS VNTR) had a lower median PFS (2.6 vs. 5.8 months) and OS (3.2 vs.14.6 months) than those with other haplotypes. Moreover, based on multivariate analysis in the validation set, patients homozygous for HT1 had a lower median PFS (2.0 vs. 6.7 months) and OS (6.4 vs. 18.0 months) than those with other haplotypes. In this context, an ePHAS study has reported that the presence of a specific haplotype of eNOS-786 (rs2070744) and eNOS VNTR polymorphisms may identify a subset of HCC patients who are more resistant to sorafenib [43].

In the literature, a few studies have identified possible predictive markers for the sorafenib therapeutic setting to treat HCC patients. Hence, Llovet et al. reported the predictive value of both VEGF-A and ANGPT-2 in HCC patients, receiving sorafenib. They found that a low plasma baseline concentration of both VEGF-A and ANGPT-2 predicted prolonged survival in HCC patients, whereas elevated plasma baseline concentration of ANGPT-2 was correlated with more aggressive tumors [104]. Furthermore, Miyahara et al. reported that high baseline ANGPT-2 serum level is complemented by the poor clinical outcome and tumor aggressiveness in HCC patients receiving sorafenib [105]. Marisi et al. reported through a multicentric retrospective study which included 135 HCC patients, all receiving sorafenib, that ANGPT2 rs55633437 TT/GT genotypes were accompanied by a lower median OS and PFS than did patients with other genotypes. Moreover, this study identified an ANGPT-2 haplotype including rs3739392, rs3739391, and rs3739390, that was associated with lower median PFS and OS in HCC patients receiving sorafenib [44].

\section{Immune Checkpoint Inhibitors; an Update of HCC Therapeutic Armamentarium}

Recently, immune checkpoint therapy has enlightened the shadow of advanced HCC therapeutic armamentarium. The activity of T cell-mediated immunity is defined through a balance between stimulatory and inhibitory signals, which shape the adaptive responses against foreign antigens while avoiding autoimmunity [106]. Physiologically, immune checkpoints function as a negative feedback regulator of inflammatory responses following T cell activation [107]. However, in the HCC context, chronic inflammation is a major player that accompanies the immune response, inducing an exhaustion state of T cells [108]. An elevated expression of inhibitory signals, including CTLA-4 and PD-1, is witnessed in exhausted T cells, limiting their effectiveness [109]. CTLA-4 expression is induced in activated T cells upon stimulatory signals from CD28/B7 and TCR/MHC binding, regardless; it is expressed constitutively in Tregs, playing a critical role in Tregs suppressive functions [110]. Being homologous to CD28, CTLA-4 competes with CD28 for their shared ligands B7-1/2, expressed on antigen-presenting cells (APCs) [111]. Nonetheless, CTLA-4 has a higher affinity for B7 ligands, counteracting the stimulatory signals induced by CD28/B7 and TCR/MHC binding [112,113]. Thus, T cells activation or energy state is defined through an intricate balance between CD28/B7 and CTLA-4/B7 signaling [110].

Furthermore, PD-1, an immunosuppressive receptor, is expressed on dendritic cells (DCs), natural killer cells (NKs), activated T cells, B cells, and monocytes [10]. The main ligand of PD-1, PD-L1, is expressed by multiple somatic cells upon exposure to proinflammatory cytokines. Another ligand for PD-1 is PD-L2, which is chiefly expressed on APCs including macrophages and DCs [114]. The binding of PD-1 to its ligands impair a 
myriad of functional processes for $\mathrm{T}$ cells including T-cell proliferation and the production of IL2, interferon-gamma (IFN- $\gamma$ ), and tumor necrosis factor-alpha (TNF- $\alpha$ ), thus reducing $\mathrm{T}$ cell survival and impairing its immune response. Furthermore, engagement of PD-1 with its ligands would interfere with downstream signaling induced by TCR, and hence reducing T cell activity [115]. Of note, regulation of T cells activity through CTLA-4 is mainly manifested in lymphoid tissues, while T cells are naïve [116]. Nevertheless, PD-1 regulates $\mathrm{T}$ cell activity at the effector stage of the immune response, especially in peripheral tissues [115].

HCC is recognized as an immunogenic tumor, whose microenvironment is brimmed with stromal and immune cells with an elevated expression of immune checkpoints, inducing an immunosuppressive microenvironment [117]. In addition, this immunosuppressive tumor microenvironment (TME) is stratified with a tolerogenic liver environment as well as an underlying inflammation [118]. Provoked by these findings, the development of ICIs is an essential requisite for the systemic management of HCC. ICIs represent a profound shift in cancer therapy, as they do not target the tumor cells, but the soldiers of the immune system, T cells. Additionally, the rationale behind ICIs is not to activate the immune system, instead, they eradicate inhibitory pathways that manage tumor cells, escape from immunosurveillance [119].

In 2017, U.S. Food and Drug Administration (FDA) granted accelerated approval to the PD-1 checkpoint inhibitor, nivolumab, followed by the approval of another PD-1 inhibitor in 2018, pembrolizumab for advanced HCC patients who had disease progression or suffered from severe adverse events with sorafenib. Nivolumab approval was granted based on the results of the particular study, CheckMate-040 [120]. This clinical trial was a phase I/II study that included two arms, a dose-escalation arm, and a dose-expansion arm as shown in Table 2. The dose-escalation phase was designed to identify the safety profile of the drug at different dose levels in three cohorts (uninfected subjects, hepatitis $C$ virus-infected subjects, and hepatitis B virus-infected subjects). Whereas the primary endpoint for the dose-expansion phase was objective response rate (ORR). This trial was followed by a phase III study, Checkmate-459 [121], conducted by Bristol Myers Squibb Company, intended to investigate the clinical efficacy of nivolumab compared to sorafenib as first-line therapy for HCC. Although, the primary endpoint for this study, OS, was not statistically significant (median OS of 16.4 months in nivolumab versus 14.7 months in the sorafenib group), yet, nivolumab revealed a tendency towards clinical improvement in ORR and complete response rate as first-line therapy for advanced HCC.

Pembrolizumab received its approval by the FDA based on the findings of the nonrandomized, multicenter, open-label phase II study Keynote-224 clinical trial [123]. This clinical trial was conducted on HCC patients intolerant or were progressing on to sorafenib. Keynote-224 reported an overall objective response rate of $17 \%$, stable disease in $44 \%$ of the cohort, while $33 \%$ showed disease progression. Furthermore, pembrolizumab demonstrated an acceptable safety profile with few adverse reactions. Based on the effectiveness and tolerability of pembrolizumab in advanced HCC, the FDA has approved the priority review application for pembrolizumab in the second-line setting for advanced HCC through a randomized, placebo-controlled phase III study, Keynote 240 clinical trial [124]. This clinical trial investigated the clinical efficacy of pembrolizumab compared to the best supportive care in patients with previously treated advanced HCC. Nonetheless, pembrolizumab failed to achieve the pre-specified statistical criteria of OS and PFS, yet, pembrolizumab reduced the risk of death by $22 \%$ and improved PFS compared with placebo. Moreover, a multitude of clinical trials has been conducted on other immune checkpoint inhibitors as illustrated in Table 2. 
Table 2. Clinical trials for immune checkpoint inhibitors as monotherapy in Hepatocellular carcinoma.

\begin{tabular}{|c|c|c|c|c|c|c|c|c|c|c|}
\hline \multirow{3}{*}{$\begin{array}{c}\text { Target. } \\
\text { Drug } \\
\text { Versus }\end{array}$} & \multicolumn{7}{|c|}{ PD-1 } & \multirow{3}{*}{$\begin{array}{c}\text { CTLA-4 } \\
\text { Tremelimumab } \\
\text { single arm } \\
\end{array}$} & \multicolumn{2}{|c|}{ PD-L1 } \\
\hline & \multicolumn{3}{|c|}{ Nivolumab } & \multicolumn{2}{|c|}{ Pembrolizumab } & \multirow{2}{*}{$\begin{array}{c}\text { Tislelizumab } \\
\text { sorafenib }\end{array}$} & \multirow{2}{*}{$\begin{array}{c}\text { Camrelizumab } \\
\text { single-arm }\end{array}$} & & \multirow{2}{*}{$\begin{array}{c}\text { Durvalumab } \\
\text { single arm }\end{array}$} & \multirow{2}{*}{$\begin{array}{c}\text { Atezolizumab } \\
\text { single arm }\end{array}$} \\
\hline & single-arm & single-arm & sorafenib & single-arm & single-arm & & & & & \\
\hline Trial name & $\begin{array}{c}\text { CheckMate-040 } \\
\text { (Dose-escalation } \\
\text { arm) }\end{array}$ & $\begin{array}{c}\text { CheckMate-040 } \\
\text { (Dose- } \\
\text { expansion } \\
\text { arm) }\end{array}$ & Checkmate-459 & KEYNOTE- 224 & KEYNOTE-240 & / & / & / & / & GO30140 \\
\hline NCT number & NCT01658878 & NCT01658878 & NCT02576509 & NCT02702414 & NCT02702401 & NCT02407990 & NCT02989922 & NCT01008358 & NCT01693562 & NCT02715531 \\
\hline Treatment line & First/second & First/second & First/second & Second & Second & First & Second & First/second & First/second & Second \\
\hline Study phase & $\mathrm{I} / \mathrm{II}$ & $\mathrm{I} / \mathrm{II}$ & III & II & III & $\mathrm{IA} / \mathrm{B}$ & II & II & $\mathrm{I} / \mathrm{II}$ & IB \\
\hline Study design & randomized & randomized & randomized & $\begin{array}{c}\text { non- } \\
\text { randomized }\end{array}$ & randomized & $\begin{array}{c}\text { non- } \\
\text { randomized }\end{array}$ & randomized & $\begin{array}{c}\text { non- } \\
\text { randomized }\end{array}$ & N/A & randomized \\
\hline $\begin{array}{l}\text { Primary end } \\
\text { points }\end{array}$ & $\begin{array}{l}\text { Safety and } \\
\text { tolerability }\end{array}$ & ORR & OS & ORR & OS / PFS & Safety & $\begin{array}{c}\text { ORR/OS at } 6 \\
\text { months }\end{array}$ & Tumor response & Safety & PFS \\
\hline ORR & 15 & 20 & 17.6 & 18 & 18.3 & 12.2 & 32 & 17.6 & 10 & 17 \\
\hline PFS (months) & 4.1 & 4 & $\mathrm{~N} / \mathrm{A}$ & $\mathrm{N} / \mathrm{A}$ & 3 & 2.1 & 2.1 & $\mathrm{~N} / \mathrm{A}$ & 2.7 & 3.4 \\
\hline TTP (months) & 3.4 & / & 7.4 & $\mathrm{~N} / \mathrm{A}$ & N/A & $\mathrm{N} / \mathrm{A}$ & N/A & 6.5 & $\mathrm{~N} / \mathrm{A}$ & $\mathrm{N} / \mathrm{A}$ \\
\hline DOR (months) & 17 & 9.9 & $\mathrm{~N} / \mathrm{A}$ & $\mathrm{N} / \mathrm{A}$ & 13.8 & $\mathrm{~N} / \mathrm{A}$ & $\mathrm{N} / \mathrm{A}$ & $\mathrm{N} / \mathrm{A}$ & $\mathrm{N} / \mathrm{A}$ & $\mathrm{N} / \mathrm{A}$ \\
\hline Result & $\begin{array}{c}\text { accepted } \\
\text { safety/tolerability }\end{array}$ & positive & $\begin{array}{l}\text { OS did not reach } \\
\text { statistical } \\
\text { significance }\end{array}$ & positive & $\begin{array}{l}\text { OS did not reach } \\
\text { statistical } \\
\text { significance }\end{array}$ & $\begin{array}{c}\text { accepted } \\
\text { safety/tolerability }\end{array}$ & positive & $\begin{array}{l}\text { Need further } \\
\text { investigation }\end{array}$ & $\begin{array}{c}\text { accepted } \\
\text { safety/tolerability }\end{array}$ & $\begin{array}{l}\text { Not effective as } \\
\text { monotherapy }\end{array}$ \\
\hline Reference & [120] & [122] & [121] & [123] & [124] & [125] & [126] & [127] & [128] & [129] \\
\hline
\end{tabular}

ORR = objective response rate; PFS = progression-free survival; TTP = time to progression; OS = overall survival; $\mathrm{DOR}=$ duration of response; $\mathrm{DCR}=$ disease control rate; $\mathrm{N} / \mathrm{A}$; not available. 


\section{Immune Checkpoint Resistance in HCC and Genomic Background}

Owing to the recent approval of ICIs as part of the therapeutic paradigm for advanced HCC, data are scarce regarding the genomic alterations associated with refractoriness to ICIs. However, Harding et al. performed a clinical sequence of 127 HCC patients receiving molecular targeted therapy, 31 of which were receiving ICIs [97]. This study provided a solid ground confirming that HCC cold tumors, defined by WNT/CTNNB1 mutations [130], promote immune escape and consequently, resistance to ICIs. Furthermore, two studies [131,132] employed RNA sequence data to classify HCC by gene expression signature involved in immunity. Both studies identified an HCC cluster with $\beta$-catenin mutations that were characterized by an immunosuppressive phenotype. On the other hand, Spahn et al. performed a retrospective multicenter analysis for in-depth characterization of responding and non-responding HCC patients receiving PD-1 inhibitors [133]. This study performed NGS in a subset of 15 HCC patients and revealed that 4 patients have alterations in WNT/ $\beta$-catenin, 1 of which showed shorter PFS than median PFS for the whole cohort. Based on this finding, Spahn et al. deduced that HCC patients could still benefit from ICIs despite alterations in the WNT/ $\beta$-catenin pathway. Furthermore, it is widely accepted that tumor mutational burden (TMB) is an indicator for the outcome of the ICI therapy $[134,135]$. It is postulated that tumors with high TMB, have more neoantigens, thus enhanced immune filtration and hence a higher potential to benefit from ICIs [136,137]. However, Xie et al. reported that HCC patients with high TMB showed lower CD8 ${ }^{+} \mathrm{T}$ cells enrichment than those patients with low TMB and hence poor prognosis [138]. Based on these findings, genomic mutations are reported to have an orchestrating role in HCC immune microenvironment that can define the response to ICIs therapy.

\section{Conclusions and Perspectives}

Despite the breakthrough in the therapeutic paradigm of HCC, drug resistance still represents a burden confronting HCC management. Of note, drug resistance is a complex and dynamic process, consequently, defining the molecular mechanisms underlying drug resistance is an essential approach. Besides, genomic heterogeneity of HCC plays a major role in the intricate response of the tumor to the applied therapy. Hence, this review aims at discussing the different resistance mechanisms confronting sorafenib as well as ICIs. Accordingly, defining predictive biomarkers with high selectivity and sensitivity to guide the rationale use of sorafenib and ICIs for HCC patients. Moreover, defining the mechanisms orchestrating the pharmacological refractoriness of HCC to the applied therapeutic drugs would aid in identifying novel strategies that can conquer cancer cells and hence, improve the outcomes of HCC patients. Furthermore, it is noteworthy that genomic studies of HCC patients can aid in tailoring personalized treatment paradigm for HCC patients through a rational selection of therapeutic drugs. Advancements in the genomic and clinical fields of HCC in the last decade provided hope for substantial improvement in the clinical outcomes of HCC patients.

Author Contributions: S.M.A., H.M.E.T. and M.O.: conceptualization; S.M.A.: writing-original draft preparation; H.M.E.T. and M.O.: editing and supervision. All authors have read and agreed to the published version of the manuscript.

Funding: This research received no external funding.

Conflicts of Interest: The authors declare no conflict of interest.

\section{References}

1. Bray, F.; Ferlay, J.; Soerjomataram, I.; Siegel, R.L.; Torre, L.A.; Jemal, A. Global cancer statistics 2018: GLOBOCAN estimates of incidence and mortality worldwide for 36 cancers in 185 countries. CA Cancer J. Clin. 2018, 68, 394-424. [CrossRef]

2. Torre, L.A.; Bray, F.; Siegel, R.L.; Ferlay, J.; Lortet-Tieulent, J.; Jemal, A. Global cancer statistics, 2012. CA A Cancer J. Clin. 2015, 65, 87-108. [CrossRef]

3. Llovet, J.M.; Zucman-Rossi, J.; Pikarsky, E.; Sangro, B.; Schwartz, M.; Sherman, M.; Gores, G. Hepatocellular carcinoma. Nat. Rev. Dis. Primers 2016, 2, 16018. [CrossRef] 
4. $\quad$ Cheng, A.L.; Kang, Y.K.; Chen, Z.; Tsao, C.J.; Qin, S.; Kim, J.S.; Luo, R.; Feng, J.; Ye, S.; Yang, T.S.; et al. Efficacy and safety of sorafenib in patients in the Asia-Pacific region with advanced hepatocellular carcinoma: A phase III randomised, double-blind, placebo-controlled trial. Lancet Oncol. 2009, 10, 25-34. [CrossRef]

5. Llovet, J.M.; Ricci, S.; Mazzaferro, V.; Hilgard, P.; Gane, E.; Blanc, J.-F.; de Oliveira, A.C.; Santoro, A.; Raoul, J.-L.; Forner, A.; et al. Sorafenib in Advanced Hepatocellular Carcinoma. N. Engl. J. Med. 2008, 359, 378-390. [CrossRef]

6. Liu, Z.; Lin, Y.; Zhang, J.; Zhang, Y.; Li, Y.; Liu, Z.; Li, Q.; Luo, M.; Liang, R.; Ye, J. Molecular targeted and immune checkpoint therapy for advanced hepatocellular carcinoma. J. Exp. Clin. Cancer Res. 2019, 38, 447. [CrossRef]

7. Cheng, A.-L.; Finn, R.S.; Qin, S.; Han, K.-H.; Ikeda, K.; Piscaglia, F.; Baron, A.D.; Park, J.-W.; Han, G.; Jassem, J.; et al. Phase III trial of lenvatinib (LEN) vs sorafenib (SOR) in first-line treatment of patients (pts) with unresectable hepatocellular carcinoma (uHCC). J. Clin. Oncol. 2017, 35, 4001. [CrossRef]

8. Mody, K.; Abou-Alfa, G.K. Systemic Therapy for Advanced Hepatocellular Carcinoma in an Evolving Landscape. Curr. Treat Options Oncol. 2019, 20, 3. [CrossRef]

9. Kudo, M. Immune Checkpoint Inhibition in Hepatocellular Carcinoma: Basics and Ongoing Clinical Trials. Oncology 2017, 92 (Suppl. S1), 50-62. [CrossRef]

10. Iñarrairaegui, M.; Melero, I.; Sangro, B. Immunotherapy of Hepatocellular Carcinoma: Facts and Hopes. Clin. Cancer Res. 2018, 24, 1518-1524. [CrossRef] [PubMed]

11. Shrestha, R.; Prithviraj, P.; Anaka, M.; Bridle, K.R.; Crawford, D.H.G.; Dhungel, B.; Steel, J.C.; Jayachandran, A. Monitoring Immune Checkpoint Regulators as Predictive Biomarkers in Hepatocellular Carcinoma. Front. Oncol. 2018, 8, 269. [CrossRef] [PubMed]

12. Makarova-Rusher, O.V.; Medina-Echeverz, J.; Duffy, A.G.; Greten, T.F. The yin and yang of evasion and immune activation in HCC. J. Hepatol. 2015, 62, 1420-1429. [CrossRef]

13. Abd El Aziz, M.A.; Facciorusso, A.; Nayfeh, T.; Saadi, S.; Elnaggar, M.; Cotsoglou, C.; Sacco, R. Immune Checkpoint Inhibitors for Unresectable Hepatocellular Carcinoma. Vaccines 2020, 8, 616. [CrossRef] [PubMed]

14. Liu, J.; Dang, H.; Wang, X.W. The significance of intertumor and intratumor heterogeneity in liver cancer. Exp. Mol. Med. 2018, 50, e416. [CrossRef] [PubMed]

15. Yang, J.D.; Hainaut, P.; Gores, G.J.; Amadou, A.; Plymoth, A.; Roberts, L.R. A global view of hepatocellular carcinoma: Trends, risk, prevention and management. Nat. Rev. Gastroenterol. Hepatol. 2019, 16, 589-604. [CrossRef]

16. Serper, M.; Taddei, T.H.; Mehta, R.; D’Addeo, K.; Dai, F.; Aytaman, A.; Baytarian, M.; Fox, R.; Hunt, K.; Goldberg, D.S.; et al. Association of Provider Specialty and Multidisciplinary Care With Hepatocellular Carcinoma Treatment and Mortality. Gastroenterology 2017, 152, 1954-1964. [CrossRef]

17. Johnson, T.M.; Overgard, E.B.; Cohen, A.E.; DiBaise, J.K. EASL-EORTC clinical practice guidelines: Management of hepatocellular carcinoma. J. Hepatol. 2012, 56, 908-943. [CrossRef]

18. Belghiti, J.; Fuks, D. Liver resection and transplantation in hepatocellular carcinoma. Liver Cancer 2012, 1, 71-82. [CrossRef]

19. Tabrizian, P.; Jibara, G.; Shrager, B.; Schwartz, M.; Roayaie, S. Recurrence of hepatocellular cancer after resection: Patterns, treatments, and prognosis. Ann. Surg. 2015, 261, 947-955. [CrossRef]

20. Yang, J.D.; Roberts, L.R. Hepatocellular carcinoma: A global view. Nat. Rev. Gastroenterol. Hepatol. 2010, 7, 448-458. [CrossRef]

21. Takayasu, K.; Arii, S.; Ikai, I.; Omata, M.; Okita, K.; Ichida, T.; Matsuyama, Y.; Nakanuma, Y.; Kojiro, M.; Makuuchi, M.; et al. Prospective Cohort Study of Transarterial Chemoembolization for Unresectable Hepatocellular Carcinoma in 8510 Patients. Gastroenterology 2006, 131, 461-469. [CrossRef]

22. Lencioni, R.; de Baere, T.; Soulen, M.C.; Rilling, W.S.; Geschwind, J.F. Lipiodol transarterial chemoembolization for hepatocellular carcinoma: A systematic review of efficacy and safety data. Hepatology 2016, 64, 106-116. [CrossRef]

23. Yao, F.Y.; Hirose, R.; LaBerge, J.M.; Davern, T.J., 3rd; Bass, N.M.; Kerlan, R.K., Jr.; Merriman, R.; Feng, S.; Freise, C.E.; Ascher, N.L.; et al. A prospective study on downstaging of hepatocellular carcinoma prior to liver transplantation. Liver Transpl. 2005, 11, 1505-1514. [CrossRef] [PubMed]

24. Wilhelm, S.; Carter, C.; Lynch, M.; Lowinger, T.; Dumas, J.; Smith, R.A.; Schwartz, B.; Simantov, R.; Kelley, S. Discovery and development of sorafenib: A multikinase inhibitor for treating cancer. Nat. Rev. Drug Discov. 2006, 5, 835-844. [CrossRef]

25. Abou-Alfa, G.K.; Niedzwieski, D.; Knox, J.J.; Kaubisch, A.; Posey, J.; Tan, B.R.; Kavan, P.; Goel, R.; Murray, J.J.; Bekaii-Saab, T.S. Phase III Randomized Study of Sorafenib Plus Doxorubicin Versus Sorafenib in Patients with Advanced Hepatocellular Carcinoma (HCC): CALGB 80802 (Alliance); American Society of Clinical Oncology: Alexandria, VA, USA, 2016.

26. Cheng, A.L.; Kang, Y.K.; Lin, D.Y.; Park, J.W.; Kudo, M.; Qin, S.; Chung, H.C.; Song, X.; Xu, J.; Poggi, G.; et al. Sunitinib versus sorafenib in advanced hepatocellular cancer: Results of a randomized phase III trial. J. Clin. Oncol. 2013, 31, 4067-4075. [CrossRef]

27. Johnson, P.J.; Qin, S.; Park, J.W.; Poon, R.T.; Raoul, J.L.; Philip, P.A.; Hsu, C.H.; Hu, T.H.; Heo, J.; Xu, J.; et al. Brivanib versus sorafenib as first-line therapy in patients with unresectable, advanced hepatocellular carcinoma: Results from the randomized phase III BRISK-FL study. J. Clin. Oncol. 2013, 31, 3517-3524. [CrossRef] [PubMed]

28. Cainap, C.; Qin, S.; Huang, W.T.; Chung, I.J.; Pan, H.; Cheng, Y.; Kudo, M.; Kang, Y.K.; Chen, P.J.; Toh, H.C.; et al. Linifanib versus Sorafenib in patients with advanced hepatocellular carcinoma: Results of a randomized phase III trial. J. Clin. Oncol. 2015, 33, 172-179. [CrossRef] [PubMed] 
29. Wilhelm, S.M.; Carter, C.; Tang, L.; Wilkie, D.; McNabola, A.; Rong, H.; Chen, C.; Zhang, X.; Vincent, P.; McHugh, M. BAY 43-9006 exhibits broad spectrum oral antitumor activity and targets the RAF/MEK/ERK pathway and receptor tyrosine kinases involved in tumor progression and angiogenesis. Cancer Res. 2004, 64, 7099-7109. [CrossRef]

30. Ito, Y.; Sasaki, Y.; Horimoto, M.; Wada, S.; Tanaka, Y.; Kasahara, A.; Ueki, T.; Hirano, T.; Yamamoto, H.; Fujimoto, J. Activation of mitogen-activated protein kinases/extracellular signal-regulated kinases in human hepatocellular carcinoma. Hepatology 1998, 27, 951-958. [CrossRef]

31. Lord, R.; Suddle, A.; Ross, P.J. Emerging strategies in the treatment of advanced hepatocellular carcinoma: The role of targeted therapies. Int. J. Clin. Pract. 2011, 65, 182-188. [CrossRef]

32. Llovet, J.M.; Bruix, J. Molecular targeted therapies in hepatocellular carcinoma. Hepatology 2008, 48, 1312-1327. [CrossRef]

33. Chen, W.; Yang, J.; Zhang, Y.; Cai, H.; Chen, X.; Sun, D. Regorafenib reverses HGF-induced sorafenib resistance by inhibiting epithelial-mesenchymal transition in hepatocellular carcinoma. FEBS Open Bio. 2019, 9, 335-347. [CrossRef]

34. Beretta, G.L.; Cassinelli, G.; Pennati, M.; Zuco, V.; Gatti, L. Overcoming ABC transporter-mediated multidrug resistance: The dual role of tyrosine kinase inhibitors as multitargeting agents. Eur. J. Med. Chem. 2017, 142, 271-289. [CrossRef] [PubMed]

35. Tandia, M.; Mhiri, A.; Paule, B.; Saffroy, R.; Cailliez, V.; Noé, G.; Farinotti, R.; Bonhomme-Faivre, L. Correlation between clinical response to sorafenib in hepatocellular carcinoma treatment and polymorphisms of P-glycoprotein (ABCB1) and of breast cancer resistance protein (ABCG2): Monocentric study. Cancer Chemother. Pharmacol. 2017, 79, 759-766. [CrossRef] [PubMed]

36. Wei, D.; Zhang, H.; Peng, R.; Huang, C.; Bai, R. ABCC2 (1249G > A) polymorphism implicates altered transport activity for sorafenib. Xenobiotica 2017, 47, 1008-1014. [CrossRef]

37. Herraez, E.; Lozano, E.; Macias, R.I.R.; Vaquero, J.; Bujanda, L.; Banales, J.M.; Marin, J.J.G.; Briz, O. Expression of SLC22A1 variants may affect the response of hepatocellular carcinoma and cholangiocarcinoma to sorafenib. Hepatology 2013, 58, 1065-1073. [CrossRef]

38. Alonso-Peña, M.; Sanchez-Martin, A.; Sanchon-Sanchez, P.; Soto-Muñiz, M.; Espinosa-Escudero, R.; Marin, J.J.G. Pharmacogenetics of hepatocellular carcinoma and cholangiocarcinoma. Cancer Drug Resist. 2019, 2, 680-709. [CrossRef]

39. Lee, Y.S.; Kim, B.H.; Kim, B.C.; Shin, A.; Kim, J.S.; Hong, S.H.; Hwang, J.A.; Lee, J.A.; Nam, S.; Lee, S.H.; et al. SLC15A2 genomic variation is associated with the extraordinary response of sorafenib treatment: Whole-genome analysis in patients with hepatocellular carcinoma. Oncotarget 2015, 6, 16449-16460. [CrossRef]

40. Brecht, K.; Schäfer, A.M.; Meyer Zu Schwabedissen, H.E. Uptake Transporters of the SLC21, SLC22A, and SLC15A Families in Anticancer Therapy-Modulators of Cellular Entry or Pharmacokinetics? Cancers 2020, 12, 2263. [CrossRef] [PubMed]

41. Zheng, Y.-B.; Zhan, M.-X.; Zhao, W.; Liu, B.; Huang, J.-W.; He, X.; Fu, S.-R.; Zhao, Y.; Li, Y.; Hu, B.-S.; et al. The relationship of kinase insert domain receptor gene polymorphisms and clinical outcome in advanced hepatocellular carcinoma patients treated with sorafenib. Med. Oncol. 2014, 31, 209. [CrossRef]

42. Scartozzi, M.; Faloppi, L.; Svegliati Baroni, G.; Loretelli, C.; Piscaglia, F.; Iavarone, M.; Toniutto, P.; Fava, G.; De Minicis, S.; Mandolesi, A.; et al. VEGF and VEGFR genotyping in the prediction of clinical outcome for HCC patients receiving sorafenib: The ALICE-1 study. Int. J. Cancer 2014, 135, 1247-1256. [CrossRef]

43. Casadei Gardini, A.; Marisi, G.; Faloppi, L.; Scarpi, E.; Foschi, F.G.; Iavarone, M.; Lauletta, G.; Corbelli, J.; Valgiusti, M.; Facchetti, F.; et al. eNOS polymorphisms and clinical outcome in advanced HCC patients receiving sorafenib: Final results of the ePHAS study. Oncotarget 2016, 7, 27988-27999. [CrossRef]

44. Marisi, G.; Petracci, E.; Raimondi, F.; Faloppi, L.; Foschi, F.G.; Lauletta, G.; Iavarone, M.; Canale, M.; Valgiusti, M.; Neri, L.M.; et al. ANGPT2 and NOS3 Polymorphisms and Clinical Outcome in Advanced Hepatocellular Carcinoma Patients Receiving Sorafenib. Cancers 2019, 11, 1023. [CrossRef] [PubMed]

45. Gillet, J.-P.; Gottesman, M.M. Mechanisms of Multidrug Resistance in Cancer. In Multi-Drug Resistance in Cancer; Zhou, J., Ed.; Humana Press: Totowa, NJ, USA, 2010; pp. 47-76.

46. Chu, X.; Korzekwa, K.; Elsby, R.; Fenner, K.; Galetin, A.; Lai, Y.; Matsson, P.; Moss, A.; Nagar, S.; Rosania, G.R.; et al. Intracellular drug concentrations and transporters: Measurement, modeling, and implications for the liver. Clin Pharm. 2013, 94, 126-141. [CrossRef] [PubMed]

47. Higgins, C.F. ABC Transporters: From Microorganisms to Man. Annu. Rev. Cell Biol. 1992, 8, 67-113. [CrossRef] [PubMed]

48. Dean, M.; Allikmets, R. Complete characterization of the human ABC gene family. J. Bioenerg. Biomembr. 2001, 33, 475-479. [CrossRef]

49. Robey, R.W.; Pluchino, K.M.; Hall, M.D.; Fojo, A.T.; Bates, S.E.; Gottesman, M.M. Revisiting the role of ABC transporters in multidrug-resistant cancer. Nat. Rev. Cancer 2018, 18, 452-464. [CrossRef] [PubMed]

50. Gatti, L.; Cossa, G.; Beretta, G.L.; Zaffaroni, N.; Perego, P. Novel insights into targeting ATP-binding cassette transporters for antitumor therapy. Curr. Med. Chem. 2011, 18, 4237-4249. [CrossRef] [PubMed]

51. Xiao, Q.; Zhou, Y.; Lauschke, V.M. Ethnogeographic and inter-individual variability of human ABC transporters. Hum. Genet. 2020, 139, 623-646. [CrossRef]

52. Lepper, E.R.; Nooter, K.; Verweij, J.; Acharya, M.R.; Figg, W.D.; Sparreboom, A. Mechanisms of resistance to anticancer drugs: The role of the polymorphic ABC transporters ABCB1 and ABCG2. Pharmacogenomics 2005, 6, 115-138. [CrossRef] [PubMed]

53. Gao, J. Association of MDR1 gene polymorphisms with the risk of hepatocellular carcinoma in the Chinese Han population. Braz. J. Med. Biol. Res. 2013, 46, 311-317. [CrossRef] 
54. Li, X.F.; He, H.B.; Zhu, Y.S.; He, J.K.; Ye, W.W.; Chen, Y.X.; Lou, L.Q. Association between the c.3751G>a genetic variant of MDR1 and hepatocellular carcinoma risk in a Chinese Han population. Asian Pac. J. Cancer Prev. 2013, 14, 5361-5365. [CrossRef] [PubMed]

55. Ren, Y.Q.; Han, J.Q.; Cao, J.B.; Li, S.X.; Fan, G.R. Association of MDR1 gene polymorphisms with susceptibility to hepatocellular carcinoma in the Chinese population. Asian Pac. J. Cancer Prev. 2012, 13, 5451-5454. [CrossRef]

56. Borel, F.; Han, R.; Visser, A.; Petry, H.; van Deventer, S.J.; Jansen, P.L.; Konstantinova, P. Adenosine triphosphate-binding cassette transporter genes up-regulation in untreated hepatocellular carcinoma is mediated by cellular microRNAs. Hepatology 2012, 55, 821-832. [CrossRef]

57. Huang, W.C.; Hsieh, Y.L.; Hung, C.M.; Chien, P.H.; Chien, Y.F.; Chen, L.C.; Tu, C.Y.; Chen, C.H.; Hsu, S.C.; Lin, Y.M.; et al. BCRP/ABCG2 inhibition sensitizes hepatocellular carcinoma cells to sorafenib. PLoS ONE 2013, 8, e83627. [CrossRef] [PubMed]

58. Timucin, M.; Alagozlu, H.; Ozdemir, S.; Ozdemir, O. Association between ABCB1 (MDR1) Gene polymorphism and unresponsiveness combined therapy in chronic hepatitis C virus. Hepat. Mon. 2013, 13, e7522. [CrossRef]

59. Fredriksson, R.; Nordström, K.J.; Stephansson, O.; Hägglund, M.G.; Schiöth, H.B. The solute carrier (SLC) complement of the human genome: Phylogenetic classification reveals four major families. FEBS Lett. 2008, 582, 3811-3816. [CrossRef]

60. Höglund, P.J.; Nordström, K.J.; Schiöth, H.B.; Fredriksson, R. The solute carrier families have a remarkably long evolutionary history with the majority of the human families present before divergence of Bilaterian species. Mol. Biol. Evol. 2011, 28, 1531-1541. [CrossRef]

61. Schlessinger, A.; Yee, S.W.; Sali, A.; Giacomini, K.M. SLC classification: An update. Clin. Pharmacol. Ther. 2013, 94, 19-23. [CrossRef] [PubMed]

62. Colas, C.; Ung, P.M.-U.; Schlessinger, A. SLC Transporters: Structure, Function, and Drug Discovery. Medchemcomm 2016, 7, 1069-1081. [CrossRef]

63. Lin, L.; Yee, S.W.; Kim, R.B.; Giacomini, K.M. SLC transporters as therapeutic targets: Emerging opportunities. Nat. Rev. Drug Discov. 2015, 14, 543-560. [CrossRef]

64. Schaller, L.; Lauschke, V.M. The genetic landscape of the human solute carrier (SLC) transporter superfamily. Hum. Genet. 2019, 138, 1359-1377. [CrossRef] [PubMed]

65. Minematsu, T.; Giacomini, K.M. Interactions of tyrosine kinase inhibitors with organic cation transporters and multidrug and toxic compound extrusion proteins. Mol. Cancer Ther. 2011, 10, 531-539. [CrossRef]

66. Zhao, Q.; Zheng, B.; Meng, S.; Xu, Y.; Guo, J.; Chen, L.-J.; Xiao, J.; Zhang, W.; Tan, Z.-R.; Tang, J.; et al. Increased expression of SLC46A3 to oppose the progression of hepatocellular carcinoma and its effect on sorafenib therapy. Biomed. Pharmacother. 2019, 114, 108864. [CrossRef]

67. Galimov, E.R.; Lohr, J.N.; Gems, D. When and How Can Death Be an Adaptation? Biochemistry 2019, 84, 1433-1437. [CrossRef]

68. Lee, Y.; Overholtzer, M. After-Death Functions of Cell Death. Yale J. Biol. Med. 2019, 92, 687-694.

69. Mizushima, N. Autophagy: Process and function. Genes Dev. 2007, 21, 2861-2873. [CrossRef] [PubMed]

70. Singh, S.S.; Vats, S.; Chia, A.Y.-Q.; Tan, T.Z.; Deng, S.; Ong, M.S.; Arfuso, F.; Yap, C.T.; Goh, B.C.; Sethi, G.; et al. Dual role of autophagy in hallmarks of cancer. Oncogene 2018, 37, 1142-1158. [CrossRef]

71. Liu, J.; Fan, L.; Wang, H.; Sun, G. Autophagy, a double-edged sword in anti-angiogenesis therapy. Med. Oncol. 2015, 33, 10. [CrossRef]

72. Che, N.; Ng, K.Y.; Wong, T.L.; Tong, M.; Kau, P.W.; Chan, L.H.; Lee, T.K.; Huen, M.S.; Yun, J.P.; Ma, S. PRMT6 deficiency induces autophagy in hostile microenvironments of hepatocellular carcinoma tumors by regulating BAG5-associated HSC70 stability. Cancer Lett. 2020. [CrossRef]

73. Zhai, B.; Hu, F.; Jiang, X.; Xu, J.; Zhao, D.; Liu, B.; Pan, S.; Dong, X.; Tan, G.; Wei, Z.; et al. Inhibition of Akt reverses the acquired resistance to sorafenib by switching protective autophagy to autophagic cell death in hepatocellular carcinoma. Mol. Cancer 2014, 13, 1589-1598. [CrossRef]

74. Shimizu, S.; Takehara, T.; Hikita, H.; Kodama, T.; Tsunematsu, H.; Miyagi, T.; Hosui, A.; Ishida, H.; Tatsumi, T.; Kanto, T.; et al. Inhibition of autophagy potentiates the antitumor effect of the multikinase inhibitor sorafenib in hepatocellular carcinoma. Int. J. Cancer 2012, 131, 548-557. [CrossRef] [PubMed]

75. Shi, Y.H.; Ding, Z.B.; Zhou, J.; Hui, B.; Shi, G.M.; Ke, A.W.; Wang, X.Y.; Dai, Z.; Peng, Y.F.; Gu, C.Y.; et al. Targeting autophagy enhances sorafenib lethality for hepatocellular carcinoma via ER stress-related apoptosis. Autophagy 2011, 7, 1159-1172. [CrossRef] [PubMed]

76. Tang, W.; Chen, Z.; Zhang, W.; Cheng, Y.; Zhang, B.; Wu, F.; Wang, Q.; Wang, S.; Rong, D.; Reiter, F.P.; et al. The mechanisms of sorafenib resistance in hepatocellular carcinoma: Theoretical basis and therapeutic aspects. Signal Transduct. Target. Ther. 2020, 5, 87. [CrossRef]

77. Shen, M.; Lin, L. Functional variants of autophagy-related genes are associated with the development of hepatocellular carcinoma. Life Sci. 2019, 235, 116675. [CrossRef]

78. Yuan, J.; Zhang, N.; Yin, L.; Zhu, H.; Zhang, L.; Zhou, L.; Yang, M. Clinical implications of the autophagy core gene variations in advanced lung adenocarcinoma treated with Gefitinib. Sci. Rep. 2017, 7, 1-10. [CrossRef]

79. Li, N.; Fan, X.; Wang, X.; Deng, H.; Zhang, K.; Zhang, X.; Han, Q.; Lv, Y.; Liu, Z. Autophagy-Related 5 Gene rs510432 Polymorphism Is Associated with Hepatocellular Carcinoma in Patients with Chronic Hepatitis B Virus Infection. Immunol. Investig. 2019, 48, 378-391. [CrossRef] [PubMed] 
80. Li, N.; Fan, X.; Wang, X.; Zhang, X.; Zhang, K.; Han, Q.; Lv, Y.; Liu, Z. Genetic association of polymorphisms at the intergenic region between PRDM1 and ATG5 with hepatitis B virus infection in Han Chinese patients. J. Med. Virol. 2020, 92, $1198-1205$. [CrossRef]

81. Mariño, G.; Niso-Santano, M.; Baehrecke, E.H.; Kroemer, G. Self-consumption: The interplay of autophagy and apoptosis. Nat. Rev. Mol. Cell Biol. 2014, 15, 81-94. [CrossRef]

82. Maiuri, M.C.; Zalckvar, E.; Kimchi, A.; Kroemer, G. Self-eating and self-killing: Crosstalk between autophagy and apoptosis. Nat. Rev. Mol. Cell Biol. 2007, 8, 741-752. [CrossRef]

83. Moreno-Càceres, J.; Fabregat, I. Apoptosis in liver carcinogenesis and chemotherapy. Hepat. Oncol. 2015, 2, 381-397. [CrossRef]

84. Niu, L.; Liu, L.; Yang, S.; Ren, J.; Lai, P.B.S.; Chen, G.G. New insights into sorafenib resistance in hepatocellular carcinoma: Responsible mechanisms and promising strategies. Biochim. Biophys. Acta Rev. Cancer 2017, 1868, 564-570. [CrossRef]

85. Shimizu, S.; Takehara, T.; Hikita, H.; Kodama, T.; Miyagi, T.; Hosui, A.; Tatsumi, T.; Ishida, H.; Noda, T.; Nagano, H.; et al. The let-7 family of microRNAs inhibits Bcl-xL expression and potentiates sorafenib-induced apoptosis in human hepatocellular carcinoma. J. Hepatol. 2010, 52, 698-704. [CrossRef] [PubMed]

86. Tutusaus, A.; Stefanovic, M.; Boix, L.; Cucarull, B.; Zamora, A.; Blasco, L.; de Frutos, P.G.; Reig, M.; Fernandez-Checa, J.C.; Marí, M.; et al. Antiapoptotic BCL-2 proteins determine sorafenib/regorafenib resistance and BH3-mimetic efficacy in hepatocellular carcinoma. Oncotarget 2018, 9, 16701-16717. [CrossRef] [PubMed]

87. Kim, E.; Viatour, P. Hepatocellular carcinoma: Old friends and new tricks. Exp. Mol. Med. 2020. [CrossRef] [PubMed]

88. Rodríguez-Hernández, M.A.; Chapresto-Garzón, R.; Cadenas, M.; Navarro-Villarán, E.; Negrete, M.; Gómez-Bravo, M.A.; Victor, V.M.; Padillo, F.J.; Muntané, J. Differential effectiveness of tyrosine kinase inhibitors in 2D/3D culture according to cell differentiation, p53 status and mitochondrial respiration in liver cancer cells. Cell Death Dis. 2020, 11, 339. [CrossRef]

89. Hussain, S.P.; Schwank, J.; Staib, F.; Wang, X.W.; Harris, C.C. TP53 mutations and hepatocellular carcinoma: Insights into the etiology and pathogenesis of liver cancer. Oncogene 2007, 26, 2166-2176. [CrossRef]

90. Wei, J.-C.; Qu, K.; Wang, Z.-X.; Wu, Q.-F.; Zhang, L.-Q.; Pang, Q.; Liu, C. Sorafenib inhibits proliferation and invasion of human hepatocellular carcinoma cells via up-regulation of p53 and suppressing FoxM1. Acta Pharmacol. Sin. 2015, 36, 241-251. [CrossRef] [PubMed]

91. Omar, H.A.; Tolba, M.F.; Hung, J.-H.; Al-Tel, T.H. OSU-2S/Sorafenib synergistic antitumor combination against hepatocellular carcinoma: The role of PKC $/$ p53. Front. Pharmacol. 2016, 7, 463. [CrossRef]

92. Pang, R.W.; Joh, J.W.; Johnson, P.J.; Monden, M.; Pawlik, T.M.; Poon, R.T. Biology of hepatocellular carcinoma. Ann. Surg. Oncol. 2008, 15, 962-971. [CrossRef]

93. Poon, R.T.; Lau, C.; Pang, R.; Ng, K.K.; Yuen, J.; Fan, S.T. High serum vascular endothelial growth factor levels predict poor prognosis after radiofrequency ablation of hepatocellular carcinoma: Importance of tumor biomarker in ablative therapies. Ann. Surg. Oncol. 2007, 14, 1835-1845. [CrossRef]

94. Marin, J.J.G.; Serrano, M.A.; Monte, M.J.; Sanchez-Martin, A.; Temprano, A.G.; Briz, O.; Romero, M.R. Role of Genetic Variations in the Hepatic Handling of Drugs. Int. J. Mol. Sci. 2020, 21, 2884. [CrossRef] [PubMed]

95. Wang, Y.; Zheng, Y.; Zhang, W.; Yu, H.; Lou, K.; Zhang, Y.; Qin, Q.; Zhao, B.; Yang, Y.; Hui, R. Polymorphisms of KDRGene are associated with coronary heart disease. J. Am. Coll. Cardiol. 2007, 50, 760-767. [CrossRef]

96. Pinyol, R.; Montal, R.; Bassaganyas, L.; Sia, D.; Takayama, T.; Chau, G.Y.; Mazzaferro, V.; Roayaie, S.; Lee, H.C.; Kokudo, N.; et al. Molecular predictors of prevention of recurrence in HCC with sorafenib as adjuvant treatment and prognostic factors in the phase 3 STORM trial. Gut 2019, 68, 1065-1075. [CrossRef] [PubMed]

97. Harding, J.J.; Nandakumar, S.; Armenia, J.; Khalil, D.N.; Albano, M.; Ly, M.; Shia, J.; Hechtman, J.F.; Kundra, R.; El Dika, I.; et al. Prospective Genotyping of Hepatocellular Carcinoma: Clinical Implications of Next-Generation Sequencing for Matching Patients to Targeted and Immune Therapies. Clin. Cancer Res. 2019, 25, 2116-2126. [CrossRef]

98. Gnoni, A.; Licchetta, A.; Memeo, R.; Argentiero, A.; Solimando, A.G.; Longo, V.; Delcuratolo, S.; Brunetti, O. Role of BRAF in Hepatocellular Carcinoma: A Rationale for Future Targeted Cancer Therapies. Medicine 2019, 55, 754. [CrossRef] [PubMed]

99. Sereno, M.; Moreno, V.; Moreno Rubio, J.; Gómez-Raposo, C.; García Sánchez, S.; Hernández Jusdado, R.; Falagan, S.; Zambrana Tébar, F.; Casado Sáenz, E. A significant response to sorafenib in a woman with advanced lung adenocarcinoma and a BRAF non-V600 mutation. Anticancer Drugs 2015, 26, 1004-1007. [CrossRef] [PubMed]

100. Casadei Gardini, A.; Chiadini, E.; Faloppi, L.; Marisi, G.; Delmonte, A.; Scartozzi, M.; Loretelli, C.; Lucchesi, A.; Oboldi, D.; Dubini, A.; et al. Efficacy of sorafenib in BRAF-mutated non-small-cell lung cancer (NSCLC) and no response in synchronous BRAF wild type-hepatocellular carcinoma: A case report. BMC Cancer 2016, 16, 429. [CrossRef]

101. Moawad, A.W.; Szklaruk, J.; Lall, C.; Blair, K.J.; Kaseb, A.O.; Kamath, A.; Rohren, S.A.; Elsayes, K.M. Angiogenesis in Hepatocellular Carcinoma; Pathophysiology, Targeted Therapy, and Role of Imaging. J. Hepatocell Carcinoma 2020, 7, 77-89. [CrossRef]

102. Huang, H.; Bhat, A.; Woodnutt, G.; Lappe, R. Targeting the ANGPT-TIE2 pathway in malignancy. Nat. Rev. Cancer 2010, 10, 575-585. [CrossRef] [PubMed]

103. Ziche, M.; Morbidelli, L. Molecular regulation of tumour angiogenesis by nitric oxide. Eur. Cytokine Netw. 2009, $20,164-170$. [CrossRef]

104. Llovet, J.M.; Peña, C.E.; Lathia, C.D.; Shan, M.; Meinhardt, G.; Bruix, J. Plasma biomarkers as predictors of outcome in patients with advanced hepatocellular carcinoma. Clin. Cancer Res. 2012, 18, 2290-2300. [CrossRef] 
105. Miyahara, K.; Nouso, K.; Tomoda, T.; Kobayashi, S.; Hagihara, H.; Kuwaki, K.; Toshimori, J.; Onishi, H.; Ikeda, F.; Miyake, Y.; et al. Predicting the treatment effect of sorafenib using serum angiogenesis markers in patients with hepatocellular carcinoma. $J$. Gastroenterol. Hepatol. 2011, 26, 1604-1611. [CrossRef] [PubMed]

106. Fares, C.M.; Van Allen, E.M.; Drake, C.G.; Allison, J.P.; Hu-Lieskovan, S. Mechanisms of Resistance to Immune Checkpoint Blockade: Why Does Checkpoint Inhibitor Immunotherapy Not Work for All Patients? Am. Soc. Clin. Oncol. Educ. Book 2019, 39, 147-164. [CrossRef] [PubMed]

107. Wei, S.C.; Sharma, R.; Anang, N.A.S.; Levine, J.H.; Zhao, Y.; Mancuso, J.J.; Setty, M.; Sharma, P.; Wang, J.; Pe'er, D.; et al. Negative Co-stimulation Constrains T Cell Differentiation by Imposing Boundaries on Possible Cell States. Immunity 2019, 50, 1084-1098.e1010. [CrossRef] [PubMed]

108. Zheng, C.; Zheng, L.; Yoo, J.K.; Guo, H.; Zhang, Y.; Guo, X.; Kang, B.; Hu, R.; Huang, J.Y.; Zhang, Q.; et al. Landscape of Infiltrating T Cells in Liver Cancer Revealed by Single-Cell Sequencing. Cell 2017, 169, 1342-1356.e1316. [CrossRef]

109. Sharma, P.; Allison, J.P. Dissecting the mechanisms of immune checkpoint therapy. Nat. Rev. Immunol. 2020, 20, 75-76. [CrossRef]

110. Dal Bo, M.; De Mattia, E.; Baboci, L.; Mezzalira, S.; Cecchin, E.; Assaraf, Y.G.; Toffoli, G. New insights into the pharmacological, immunological, and CAR-T-cell approaches in the treatment of hepatocellular carcinoma. Drug Resist. Updates 2020, 51, 100702. [CrossRef] [PubMed]

111. Collins, A.V.; Brodie, D.W.; Gilbert, R.J.C.; Iaboni, A.; Manso-Sancho, R.; Walse, B.; Stuart, D.I.; van der Merwe, P.A.; Davis, S.J. The Interaction Properties of Costimulatory Molecules Revisited. Immunity 2002, 17, 201-210. [CrossRef]

112. Masteller, E.L.; Chuang, E.; Mullen, A.C.; Reiner, S.L.; Thompson, C.B. Structural Analysis of CTLA-4 Function In Vivo. J. Immunol. 2000, 164, 5319-5327. [CrossRef] [PubMed]

113. Fallarino, F.; Fields, P.E.; Gajewski, T.F. B7-1 engagement of cytotoxic T lymphocyte antigen 4 inhibits T cell activation in the absence of CD28. J. Exp. Med. 1998, 188, 205-210. [CrossRef] [PubMed]

114. Baumeister, S.H.; Freeman, G.J.; Dranoff, G.; Sharpe, A.H. Coinhibitory Pathways in Immunotherapy for Cancer. Annu. Rev. Immunol. 2016, 34, 539-573. [CrossRef]

115. Keir, M.E.; Butte, M.J.; Freeman, G.J.; Sharpe, A.H. PD-1 and Its Ligands in Tolerance and Immunity. Annu. Rev. Immunol. 2008, 26, 677-704. [CrossRef] [PubMed]

116. Fife, B.T.; Bluestone, J.A. Control of peripheral T-cell tolerance and autoimmunity via the CTLA-4 and PD-1 pathways. Immunol. Rev. 2008, 224, 166-182. [CrossRef] [PubMed]

117. Pinato, D.J.; Guerra, N.; Fessas, P.; Murphy, R.; Mineo, T.; Mauri, F.A.; Mukherjee, S.K.; Thursz, M.; Wong, C.N.; Sharma, R.; et al. Immune-based therapies for hepatocellular carcinoma. Oncogene 2020, 39, 3620-3637. [CrossRef]

118. Pinter, M.; Jain, R.K.; Duda, D.G. The Current Landscape of Immune Checkpoint Blockade in Hepatocellular Carcinoma: A Review. JAMA Oncol. 2020. [CrossRef]

119. Sharma, P.; Allison, J.P. The future of immune checkpoint therapy. Science 2015, 348, 56-61. [CrossRef]

120. El-Khoueiry, A.B.; Sangro, B.; Yau, T.; Crocenzi, T.S.; Kudo, M.; Hsu, C.; Kim, T.Y.; Choo, S.P.; Trojan, J.; Welling, T.H.R.; et al. Nivolumab in patients with advanced hepatocellular carcinoma (CheckMate 040): An open-label, non-comparative, phase $1 / 2$ dose escalation and expansion trial. Lancet 2017, 389, 2492-2502. [CrossRef]

121. Yau, T.; Park, J.W.; Finn, R.S.; Cheng, A.L.; Mathurin, P.; Edeline, J.; Kudo, M.; Han, K.H.; Harding, J.J.; Merle, P.; et al. CheckMate 459: A randomized, multi-center phase III study of nivolumab (NIVO) vs sorafenib (SOR) as first-line (1L) treatment in patients (pts) with advanced hepatocellular carcinoma (aHCC). Ann. Oncol. 2019, 30, v874-v875. [CrossRef]

122. Kudo, M.; Matilla, A.; Santoro, A.; Melero, I.; Gracian, A.C.; Acosta-Rivera, M.; Choo, S.P.; El-Khoueiry, A.B.; Kuromatsu, R.; El-Rayes, B.F.; et al. Checkmate-040: Nivolumab (NIVO) in patients (pts) with advanced hepatocellular carcinoma (aHCC) and Child-Pugh B (CPB) status. J. Clin. Oncol. 2019, 37, 327. [CrossRef]

123. Zhu, A.X.; Finn, R.S.; Edeline, J.; Cattan, S.; Ogasawara, S.; Palmer, D.; Verslype, C.; Zagonel, V.; Fartoux, L.; Vogel, A.; et al. Pembrolizumab in patients with advanced hepatocellular carcinoma previously treated with sorafenib (KEYNOTE-224): A non-randomised, open-label phase 2 trial. Lancet Oncol. 2018, 19, 940-952. [CrossRef]

124. Finn, R.S.; Ryoo, B.Y.; Merle, P.; Kudo, M.; Bouattour, M.; Lim, H.Y.; Breder, V.; Edeline, J.; Chao, Y.; Ogasawara, S.; et al. Pembrolizumab As Second-Line Therapy in Patients With Advanced Hepatocellular Carcinoma in KEYNOTE-240: A Randomized, Double-Blind, Phase III Trial. J. Clin. Oncol. 2020, 38, 193-202. [CrossRef] [PubMed]

125. Deva, S.; Lee, J.-S.; Lin, C.-C.; Yen, C.-J.; Millward, M.; Chao, Y.; Keam, B.; Jameson, M.; Hou, M.-M.; Kang, Y.-K. A phase Ia/Ib trial of tislelizumab, an anti-PD-1 antibody (ab), in patients (pts) with advanced solid tumors. Ann. Oncol. 2018, 29, x24-x25. [CrossRef]

126. Qin, S.; Ren, Z.; Meng, Z.; Chen, Z.; Chai, X.; Xiong, J.; Bai, Y.; Yang, L.; Zhu, H.; Fang, W. Camrelizumab in patients with previously treated advanced hepatocellular carcinoma: A multicentre, open-label, parallel-group, randomised, phase 2 trial. Lancet Oncol. 2020, 21, 571-580. [CrossRef]

127. Sangro, B.; Gomez-Martin, C.; de la Mata, M.; Iñarrairaegui, M.; Garralda, E.; Barrera, P.; Riezu-Boj, J.I.; Larrea, E.; Alfaro, C.; Sarobe, P. A clinical trial of CTLA-4 blockade with tremelimumab in patients with hepatocellular carcinoma and chronic hepatitis C. J. Hepatol. 2013, 59, 81-88. [CrossRef]

128. Powles, T.; O’Donnell, P.H.; Massard, C.; Arkenau, H.-T.; Friedlander, T.W.; Hoimes, C.J.; Lee, J.L.; Ong, M.; Sridhar, S.S.; Vogelzang, N.J. Efficacy and safety of durvalumab in locally advanced or metastatic urothelial carcinoma: Updated results from a phase 1/2 open-label study. JAMA Oncol. 2017, 3, e172411. [CrossRef] 
129. Lee, M.S.; Ryoo, B.-Y.; Hsu, C.-H.; Numata, K.; Stein, S.; Verret, W.; Hack, S.P.; Spahn, J.; Liu, B.; Abdullah, H. Atezolizumab with or without bevacizumab in unresectable hepatocellular carcinoma (GO30140): An open-label, multicentre, phase 1b study. Lancet Oncol. 2020, 21, 808-820. [CrossRef]

130. Sia, D.; Jiao, Y.; Martinez-Quetglas, I.; Kuchuk, O.; Villacorta-Martin, C.; de Moura, M.C.; Putra, J.; Camprecios, G.; Bassaganyas, L.; Akers, N. Identification of an immune-specific class of hepatocellular carcinoma, based on molecular features. Gastroenterology 2017, 153, 812-826. [CrossRef]

131. Fujita, M.; Yamaguchi, R.; Hasegawa, T.; Shimada, S.; Arihiro, K.; Hayashi, S.; Maejima, K.; Nakano, K.; Fujimoto, A.; Ono, A. Classification of primary liver cancer with immunosuppression mechanisms and correlation with genomic alterations. EBioMedicine 2020, 53, 102659. [CrossRef]

132. Shimada, S.; Mogushi, K.; Akiyama, Y.; Furuyama, T.; Watanabe, S.; Ogura, T.; Ogawa, K.; Ono, H.; Mitsunori, Y.; Ban, D. Comprehensive molecular and immunological characterization of hepatocellular carcinoma. EBioMedicine 2019, 40, 457-470. [CrossRef]

133. Spahn, S.; Roessler, D.; Pompilia, R.; Gabernet, G.; Gladstone, B.P.; Horger, M.; Biskup, S.; Feldhahn, M.; Nahnsen, S.; Hilke, F.J.; et al. Clinical and Genetic Tumor Characteristics of Responding and Non-Responding Patients to PD-1 Inhibition in Hepatocellular Carcinoma. Cancers 2020, 12, 3830. [CrossRef]

134. Le, D.T.; Uram, J.N.; Wang, H.; Bartlett, B.R.; Kemberling, H.; Eyring, A.D.; Skora, A.D.; Luber, B.S.; Azad, N.S.; Laheru, D. PD-1 blockade in tumors with mismatch-repair deficiency. N. Engl. J. Med. 2015, 372, 2509-2520. [CrossRef]

135. Le, D.T.; Durham, J.N.; Smith, K.N.; Wang, H.; Bartlett, B.R.; Aulakh, L.K.; Lu, S.; Kemberling, H.; Wilt, C.; Luber, B.S. Mismatch repair deficiency predicts response of solid tumors to PD-1 blockade. Science 2017, 357, 409-413. [CrossRef]

136. Rizvi, N.A.; Hellmann, M.D.; Snyder, A.; Kvistborg, P.; Makarov, V.; Havel, J.J.; Lee, W.; Yuan, J.; Wong, P.; Ho, T.S. Mutational landscape determines sensitivity to PD-1 blockade in non-small cell lung cancer. Science 2015, 348, 124-128. [CrossRef] [PubMed]

137. Johnson, D.B.; Frampton, G.M.; Rioth, M.J.; Yusko, E.; Xu, Y.; Guo, X.; Ennis, R.C.; Fabrizio, D.; Chalmers, Z.R.; Greenbowe, J. Targeted next generation sequencing identifies markers of response to PD-1 blockade. Cancer Immunol. Res. 2016, 4, 959-967. [CrossRef]

138. Xie, F.; Bai, Y.; Yang, X.; Long, J.; Mao, J.; Lin, J.; Wang, D.; Song, Y.; Xun, Z.; Huang, H.; et al. Comprehensive analysis of tumour mutation burden and the immune microenvironment in hepatocellular carcinoma. Int. Immunopharmacol. 2020, $89,107135$. [CrossRef] 